\title{
Granulocyte/Macrophage Colony-Forming Units from Cord Blood of Premature and Full-Term Neonates: Its Role in Ontogeny of Human Hemopoiesis
}

\author{
DER-CHERNG LIANG, SHEAU-WEN MA, MARIE LIN-CHU, AND CHUNG-CHI LAN \\ Departments of Pediatrics [D.C.L.], Medical Research [S.W.M. and M.L.C.], and Obstetrics/Gynecology \\ [C.C.L.], Mackay Memorial Hospital, 92, Sec. 2, Chung-San North Road, \\ Taipei, Taiwan, 10449, Republic of China
}

\begin{abstract}
It is still uncertain whether the yolk sac is the only origin of hemopoietic stem cells during fetal development. We studied the level of circulating granulocyte/macrophage colony-forming unit (CFU-GM) from the 23rd week of gestation to fullterm, trying to delineate its role in the ontogeny of human hemopoiesis. Cord blood samples were collected from 45 healthy premature neonates and 91 healthy full-term neonates. CFU-GM assays were performed using a single agar layer system with human placental conditioned medium as a source of colony stimulating activity. The mean numbers of colonies produced from the cord blood samples of the premature and full-term neonates were $116 \pm 185$ (SD) and $96 \pm 113 / 2$ $\times 10^{5}$ mononuclear cells, respectively. There was no statistical difference between the numbers of colonies of the two groups (Mann-Whitney test, $p>0.05$ ). These results indicate that the level of circulating CFU-GM from the 23rd week of gestation to full term is constantly high and add credence to the assumption that CFU-GM are produced not only from the yolk sac but also from other hemopoietic sites. (Pediatr Res 24:701-702, 1988)
\end{abstract}

\section{Abbreviations}

CFU-GM, granulocyte/macrophage colony-forming units HSC, hemopoietic stem cells

$\mathrm{BM}$, bone marrow

CB, cord blood

PB, peripheral blood

MNC, mononuclear cells

YS, yolk sac

The hemopoietic stem cells which form colonies in vitro in the presence of colony stimulating activity are designated as colonyforming units in culture and regarded as the committed stem cells of the granulocyte and monocyte-macrophage series (1). During human intrauterine development, hemopoiesis has three phases. In the embryo, erythroblasts arise in the YS. From the 6th wk of gestation, erythropoiesis is transferred to the liver which is the most active site of hemopoiesis from the 6th to the 12 th wk of gestation. Although the HSC populations are exclusively erythropoietic, CFU-GM are present in fetal liver in a level

Received September 25, 1987; accepted August 8, 1988.

Correspondence Dr. Der-Cherng Liang, Department of Pediatrics, Mackay Memorial Hospital, 92, Sec. 2, Chung-San North Road, Taipei, Taiwan 10449, Republic of China. similar to (2) or even higher than (3) that in the adult BM. Hepatic hemopoiesis declines in the 3rd trimester and ceases soon after birth. The onset of BM hemopoiesis occurs during the $15-16$ th wk of gestation (4). Whether the YS is the only origin of $\mathrm{HSC}$ remains to be clarified.

A high level of CFU-GM has been found in human fetal blood from the 12th to the 18th (5) and the 13th to the $21 \mathrm{st}(4)$ wk of gestation. CFU-GM has also been noted to be increased in CB of full-term neonates (6-14). In this report, we studied the level of circulating CFU-GM from the 23rd wk of gestation to full term, trying to delineate its role in the ontogeny of human hemopoiesis.

\section{MATERIALS AND METHODS}

Materials. $\mathrm{CB}$ was collected in sterile tubes containing heparin immediately after delivery and was kept at $4^{\circ} \mathrm{C}$ for less than 12 $\mathrm{h}$ before culture. Altogether, $136 \mathrm{CB}$ samples were collected with 45 being from healthy premature neonates and 91 being from healthy full-term neonates. The gestation ages of the premature neonates ranged from 23 to $36 \mathrm{wk}$ (median, $34 \mathrm{wk}$ ), and their birth weights ranged from 650 to $2900 \mathrm{~g}$ (median, $2025 \mathrm{~g}$ ). The $\mathrm{BM}$ samples were collected from 52 pediatric patients with normal white blood cell counts, differential counts and normal marrow findings. The BM aspirations were performed for differential diagnosis of thrombocytopenia or unexplained hepatosplenomegaly, or as a staging procedure for solid tumors. The PB samples were collected from 33 healthy adult volunteers.

Methods. CFU-GM assays were performed using a single agar layer system with human placental conditioned medium as a source of colony-stimulating activity (15). CB and BM MNC were cultured at a concentration of $2 \times 10^{5}$ cells and PB at $1 \times$ $10^{6}$ cells in $1 \mathrm{ml}$ of $\alpha$-medium containing $10 \%$ human placental conditioned medium, $20 \%$ fetal calf serum, and $0.3 \%$ agar. Duplicate cultures were prepared for each sample and incubated at $37^{\circ} \mathrm{C}$ in a fully humidified incubator with a constant flow of $7.5 \% \mathrm{CO}_{2}$ in air. The duration of incubation for $\mathrm{CB} \mathrm{MNC}$ was 10 days and for BM and PB MNC was 7 days. Aggregates of 840 cells were counted as clusters and of $>40$ cells as colonies (16).

Statistical analysis. The Mann-Whitney test was used to determine the significance of the difference between the results of two groups.

\section{RESULTS}

The data for granulocyte-macrophage colony and cluster formations of CB, BM, and PB are presented in Table 1. Statistically, 
Table 1. Numbers of granulocyte-macrophage colonies and clusters from $C B, B M\left(\right.$ per $\left.2 \times 10^{5} M N C\right)$ and $P B\left(\text { per } 1 \times 10^{6} M N C\right)^{*}$

\begin{tabular}{ccccc}
\hline & $\begin{array}{c}\text { CB of } \\
\text { premature neonates }\end{array}$ & $\begin{array}{c}\text { CB of } \\
\text { full-term neonates }\end{array}$ & BM & PB \\
\hline $\begin{array}{l}\text { No. of colo- } \\
\text { nies }\end{array}$ & $58,(7-878),(116 \pm 185)$ & $57,(7-731),(96 \pm 113)$ & $173,(20-651),(206 \pm 155)$ & $5,(0-17),(7 \pm 5)$ \\
$\begin{array}{l}\text { No. of clusters } \\
\text { No. of samples }\end{array}$ & $70,(13-487),(121 \pm 120)$ & $52,(7-725),(110 \pm 148)$ & $281,(47-718),(308 \pm 162)$ & $3,(0-10),(4 \pm 3)$. \\
\end{tabular}

* The data are presented as median, (range), (mean $\pm \mathrm{SD})$.

there was no significant difference in the numbers of colonies from $\mathrm{CB}$ between premature neonates and full-term neonates ( $p$ $>0.05$ ). Also, there was no statistical difference in the numbers of clusters from $\mathrm{CB}$ between premature neonates and full-term neonates $(p>0.05)$. The pediatric $\mathrm{BM}$ gave rise to more colonies than did the CB from both premature neonates $(p<0.0001)$ and full-term neonates $(p<0.0001)$. Also, $\mathrm{BM}$ gave rise to more clusters than did the CB from premature neonates $(p<0.0001)$ and $\mathrm{CB}$ from full-term neonates $(p<0.0001)$. $\mathrm{CB}$ and $\mathrm{BM}$ gave rise to many more colonies and clusters than did $\mathrm{PB}$. The colony and cluster numbers $/ \mathrm{ml}$ of $\mathrm{CB}$ were counted on 20 samples based on the concentrations of MNC in CB. And there were $3989 \pm 5606$ colonies $/ \mathrm{ml}$ and $4127 \pm 4510$ clusters $/ \mathrm{ml}$ (mean \pm SD) formed.

\section{DISCUSSION}

In chicken embryos, the HSC of intraembryonic origin are scattered all over the body and are especially numerous in the dorsal mesentery in the vicinity of the aorta (17). In quail embryos, the foci of the intraembryonic HSC are localized in the angle of the duct of Cuvier and anterior cardinal vein (17). In mice, an earlier study showed that YS was the only source of CFU-GM formation, and these HSC migrated via PB to colonize other hemopoietic organs (18). However, Barker (19) demonstrated a maximum number of CFU-GM in PB of 12-day embryonic mice, a stage at which the liver shows a fully expressed hemopoietic capacity. This finding may indicate that the liver is capable of adding HSC to PB (20). The observation of a constantly high number of CFU-GM in PB of mice during embryonic development till the end of gestation indicates that other hemopoietic organs are also producers of HSC (20).

Our results show that in humans the level of circulating CFUGM from the 23rd wk of gestation to full term is constantly high. Since a high level of CFU-GM was also found in human fetal blood during the 12-18th (5) and the 13-21st (4) wk of gestation, it is concluded that in humans, just as in mice, there is a high level of circulating CFU-GM from the 12 th wk of gestation to full term. Therefore, because CFU-GM in mice are produced in YS and other hemopoietic sites (20), it is assumed that this is the same in humans.

Acknowledgment. The authors thank the staff of the delivery room at the Mackay Memorial Hospital who collected the cord blood samples.

\section{REFERENCES}

1. Moore MAS, Williams N, Metcalf D 1972 Purification and characterization of the in vitro colony forming cells in monkey hemopoietic tissue. $\mathrm{J}$ Cell Physiol 79:283-292

2. Barak Y, Karov Y, Levin S, Soroker N, Barash A, Lancet M, Nir E 1980 Granulocyte-macrophage colonies in cultures of human fetal liver cells: morphologic and ultrastructural analysis of proliferation and differentiation. Exp Hematol 8:837-844

3. Moore MAS, Williams N 1973 Analysis of proliferation and differentiation of foetal granulocyte macrophage progenitor cells in haemopoietic tissue. Cell Tissue Kinet 6:461-476

4. Hann IM, Bodger MP, Hoffbrand AV 1983 Development of pluripotent hematopoietic progenitor cells in the human fetus. Blood 62:118-123

5. Linch DC, Knott LJ, Rodeck CH, Huehns ER 1982 Studies of circulating hemopoietic progenitor cells in human fetal blood. Blood 59:976-979

6. Knudtzon S 1974 In vitro growth of granulocytic colonies from circulating cells in human cord blood. Blood 43:357-361

7. Gabutti V, Foa R, Mussa F, Aglietta M 1975 Behaviour of human haemopoietic stem cells in cord and neonatal blood. Haematologica 60:492

8. Prindull G, Prindull B, Meulen NVD 1980 Haematopoietic stem cells (CFUc) in human cord blood. Acta Paediatr Scand 67:413-416

9. Kirshner JJ, Goldberg J 1980 Types of colonies formed by normal human bone marrow, peripheral blood and umbilical cord blood CFUc. Exp Hematol 8:1202-1207

10. Di Landro G, Dresch C, Poirier O 1980 Granulomonocyte colony-forming cells in cord blood. Nouv Rev Fr Hematol 22:371-382

11. Ueno Y, Koizumi S, Yamagami M, Miura M, Taniguchi N 1981 Characterization of hemopoietic stem cells (CFUc) in cord blood. Exp Hematol 9:716722

12. Ijima H, Suda T, Miura Y 1982 Predominance of macrophage-colony formation in human cord blood. Exp Hematol 10:234-240

13. Shih L-Y, Wen K-W, Chang C-Y 1983 In vitro growth of granulocytemacrophage colonies from normal human bone marrow, peripheral blood and umbilical cord blood. J Formosan Med Assoc 82:879-885

14. Issaragrisil S, Grilli G, Nothdurft W, Fliedner TM 1984 Characterization of erythroid and granuloctye monocyte progenitors in human cord blood. Scand J Haematol 33:317-322

15. Burgess AW, Wilson EMA, Metcalf D 1977 Stimulation by human placental conditioned medium of hemopoietic colony formation by human marrow cells. Blood 49:573-583

16. Liang D-C, Shen E-Y, Chyou S-C 1986 To early distinguish neonatal transient leukemoid proliferation from congential leukemia by in vitro cell growth. Blut 53:101-106

17. Le Douarin NM, Dieterlen-Lievre F, Oliver PD 1984 Ontogeny of primary lymphoid organs and lymphoid stem cells. Am J Anatomy 170:261-299

18. Moore MAS, Metcalf D 1970 Ontogeny of the haemopoietic system: yolk sac origin of in vivo and in vitro colony forming cells in the developing mouse embryo. Br J Haematol 18:279-296

19. Barker JE 1970 Embryonic mouse peripheral blood colony-forming units. Nature 228:1305-1306

20. Fishman P, Zahavi I, Djaldetti M 1984 In vitro colony-forming cells in embryonic mouse liver, spleen and peripheral blood. Acta Haematol 71:356358 . 